\section{THE VOLCANOES OF ICELAND}

DURING the past year the Danish Government despatched the well-known geologist, Prof. Johnstrup, to Iceland, for the purpose of making a thorough scientific investigation of the scene of the recent volcanic disturbances. A short time since he laid before the Danish Parliament a report of his journey, with a brief account of the results so far obtained. The first part of the expedition was devoted to the volcanoes in the Dyngju Mountains, encircling the valley of Askja, and was accompanied with many difficulties resulting from the conformation of the region and the prevalence of violent snow-storms. The mountains themselves are not of volcanic origin, but consist of basalt and palagonitebreccia. In former times the Askja Valley was evidently much deeper than at present. Repeated flows of lava have gradually filled it up, and these Prof. Johnstrup be- lieves to have occurred within the historic period, although no mention of volcanic disturbances in this district is to be found in the annals of the island. Along the outer edge of the Dyngju Mountains are numerous craters, some of considerable size, which have contributed most of the lava covering the plain of Odadahrann to the extent of sixty square geographical miles. Part of this enormous quantity of lava had its origin in the neighbouring volcano of Trölladyngja. It is, however, sharply distinguished from the twisted, contorted, masses of the former, by its more regular character and smooth crusts. In the neighbouthood of the newly-formed craters the earth is covered to the distance of over a mile with the bright yellow pumice-sione ejected during the eruption of March 29, 1875. Most of the pieces are seven to-eight inches in diameter ; many contained two to three cubic feet. In places where the pumice-stone is several feet in depth, it covers a layer of snow twenty-five

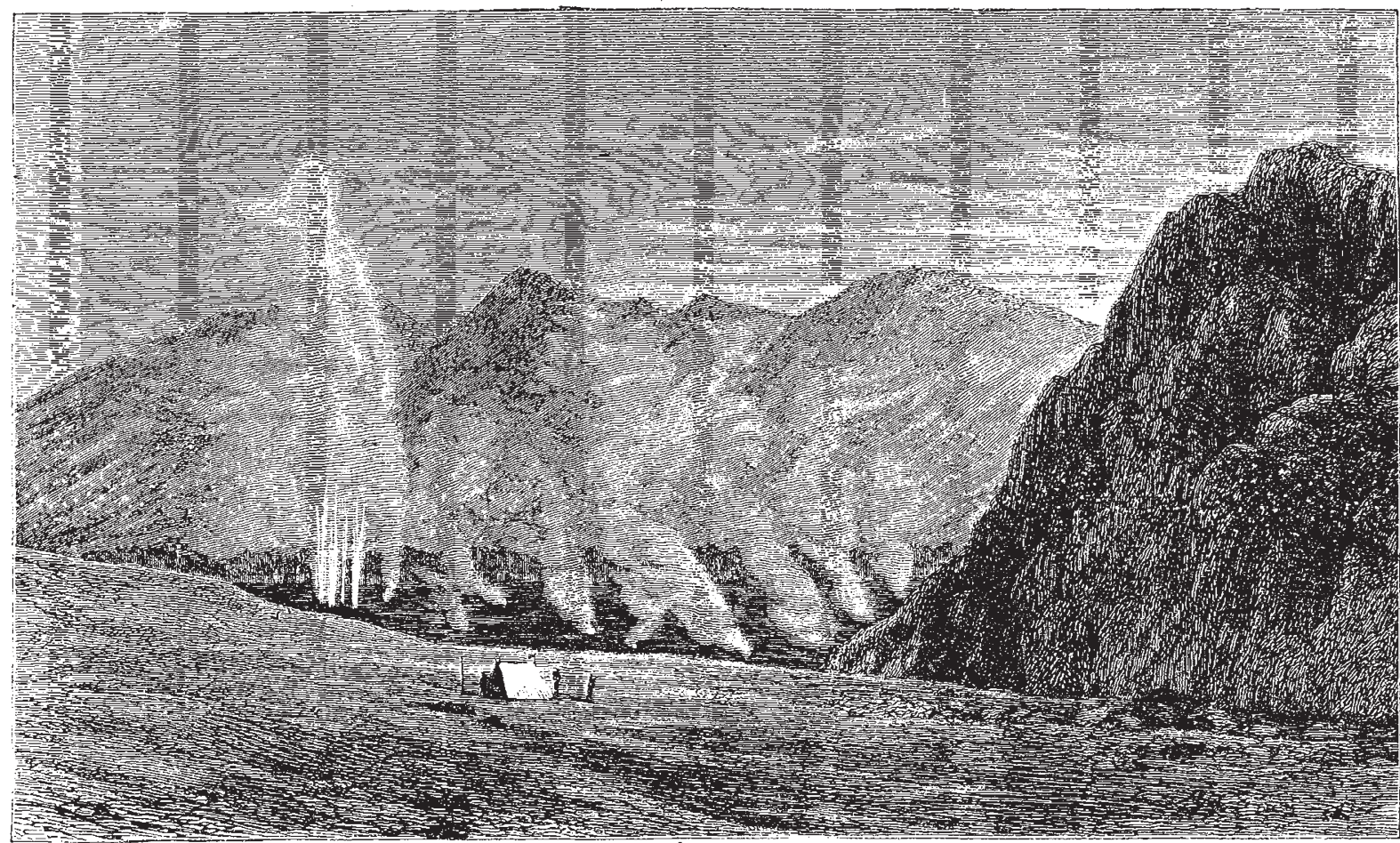

The Oskjagja. (from Watts's "Across the Vatna Jökull.")

feet deep, which fell in the winter of 1874-1875, and has been protected from the effects of solar warmth by the feeble conductive power of the pumice-stone. It is fortunate for the land that the outbreak was of this nature, for from its lightness the pumice-stone can be easily removed from the surface of the country. The party examined the most northerly of the craters, which was 300 feet wide and I 50 feet deep. It was filled with steam, which was driven out with such force as to give rise to a most deafening roar. No solid matter, however, was borne along with the vapour. Not far from the crater an extensive depression in the valley of Askja has taken place, and the fresh surfaces of rock exposed thereby give a clear picture of the peculiar formation of the valley by successive deposits. It presents a remarkable similarity to the basalt and dolerite formations so prevalent in the mountain ranges of Iceland.

The most surprising feature of these late eruptions was the ejection of such enormous masses of pumice-stone, while not a trace of a lava stream is to be found. A similar outbreak is not mentioned in the records of the island. On account also of the vast development of steam, which gave rise to the pumice-stone formation, they are without a parallel amongst volcanic phenomena. At present the craters are to be regarded as gigantic steam escape tubes, the activity of which will continue for an uncertain period, but with gradually decreasing intensity. As long as these safety valves remain open it is not probable that a repetition of the eruptions will occur in the immediate future.

The volcanoes in Myvatns Oræfi were found to present entirely different characteristics. This barren plain is about thirty-five miles long and thirteen miles wide. Suddenly, on February 18, 1875, a volcano appeared in the centre. Four others appeared at subsequent dates, all of the craters falling into a straight line north and south. No eruptions have occurred here within historic times. The mass of lava which issued from these various craters is estimated at $10,000,000,000$ cubic feet, eighteen times the amount supposed to have been emitted by Vesuvius in 1794 and 1855 . The lava was basaltic and 
viscous when emitted, and crystals of chloride of ammonium were found in the vicinity of the craters. Only slight traces of the volcanic action remain now, where warm air arises from the thicker layers of lava.

Prof. Johnstrup is engaged at present in the preparation of maps showing the successive deposits of lava from the older eruptions, as well as from the more recent. The Hlidar ranse, hitherto regarded as a palagonite formation, was found by him to consist of trachytic masses, a more ancient, and in Iceland rarer, formation than palagonite.

In connection with Prof. Johnstrup's Report we may refer to Mr. Watts's interesti ig narrative of his journey across the Vatna Jökull. ${ }^{1}$ Mr. Watts's name is already well known in connection with recent exploration iti Iceland. He has for long had a strong desire to cross the Vatna Jökull, and at last succeeded. We infer-for his narrative is almost innocent of dates-that the feat took place in the summer of 1875 . The preparations made remind one of those necessary before setting out on an Arciic expedition, and the whole journey bore a strong resemblance to those sledge journeys we read of in connection with the recent polar expedition. There were sledyes, tent, sleeping bag, pemmican, and similar stores; frost-bites, snow-storms, and weary detentions for favourable weather and ground. The Vatna Jökull, we learn from Mr. Watts, is a vast accumulation of volcanoes, ice, ano snow, covering an area of over 3,000 square miles in the south-east of lceland. It is a plateau of from 4,000 to 6,000 feet high, is surrounded on all sides by volcanic mounrains, and gives birth to glaciers on various sides. On the south especially it seems to be advancing, and there the glacier may soon reach the sea and gire birth to miniature icebergs. Mr. Watts crossed at the east side, and after suffering considerable hardships he and his party reached the farm of Grimstadr, in the north of Iceland. From here Mr. Watts returned southwards to the northern edge of the Vatna jökull for the purpose of examining the Oskjagja, a huge and active crater on the south of the Askja, or Dyngjufjall, referred to by Prof. Johnstrup. Mr. Watts yives many interesting and important details concerning this mountain and the desolate country in its vicinity, covered with pumice dust and other products of eruption. Mr. Watts also visited the region around the Myvatn Lake, near which are the sulphur deposits which a company was started to work. After visiting one or two places on the nirth coast he returned to Reykjavik right across the centre of the country. Notwithstanding the defects of style, the want of dates, and occasional vagueness, Mr. Watts's narrative is a really valuable and interesting contribution to a knowledge of the physical geography of Iceland, and he has the honour to be the first, so far as known, to have crossed the great Icelandic waste.

\section{THE ANTIQUITY OF MAN}

$\mathrm{IN}$ the number for May 24 we gave abstracts of the 1 papers read by Professors Dawkins and Hughes, and Mr. Tiddeman at the Conference on the subject of the Antiquity of Man at the Anthropological Institute, and this week we give a report of the discussion which followed the reading of these papers, the remarks of the various speakers, we may state, having been revised by themselves.

Prof. Busk wished to explain, before the discussion commenced, the circumstances connected with the interesting fragment of bone, for the determination of which he was personally responsible. This "bone of contention" was represented by the cast which he held in his hand. He was surprised that such a large superstructure had been raised upon that particular piece. It was merely a fragment, evid ently of a fibula, one of the most variable bones in the body. It was received by him, together with a large collection of other remins from $\mathrm{Mr}$. Tiddeman,

I "Across the Vatna Jökull; or, Scenes in Ic $\_$land," by William Lord Watts. (London: Longmans and Co.) and for a long time remained an insoluble problem. At last, after many conjectural delerininations by himself and others, Mr. James Flowtr, the well-lswown articulator to the Royal Col lege of Surgeons, discovered in the College a human fibula of unusual size, and with which, as he pointed out, the Victoria Cave bone corresponded in many particulars. This determination, with the reasms for it, and illu-trated by figures, was pablished in the Fourn $l$ of the Institute. At the same time Mr. Bunk was perfectly.open to he convinced that it might be ursine. But alh:ugh Prof. Boyd Dawkins had been good enough to show him bones of fossil bears of surprising size, none of them quite came up to the one in question. Nor at Toulouse, where there is such an enormous collection of ursine remains, did Mr. Busk observe any of corresponding dimensions. He was himself still disposed to regard the specimen as a fragment of an abnormally large human fibula, but thought that at present it would be unsafe to build any strong conc usions upon it.

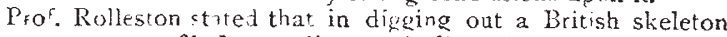
he came upon a fibula standing vertically. They went on and he took out every bone with nis own hands and they came to a skeleton, contrac ea in the ordinary British way, which was whole, minus that one fibula. A man is put into the ground with his flesh and bones all upon him, the flesh decays, the stones get upon him, the bones are loose and consequently the fibula gret: disturbed. Even granting that the one before them was a human fibula he would lay less stress upon it than on any other bone. In the Gibraltar Cave series the fibulæ, owing to their liability to displacement, were very often missing. He did not in the least dispute the antiquity of the deposits in the Victoria Cave. With respect to the reindeer and the hippopotamus, they might judge somelhing trom what they saw in the life and in the fesh. He had seen the hippepotamus walking about in very cold weather in the Zoological Gardens seeming extremely comfortable, and the rhinoceros and reindeer the same. Mr Evelyn, of Wotton, had kept reindeer alive for considerable periods in England. At the time of Julius Casar the reindeer lived in Germany. At the present time the reindeer was the food of the tiger in the Isle of Saghalien, North of Japan. There the tiger, which has a black and thick fur, crosses the ice after the reindeer. The skull of a young hippopotamus was found in England, showing that the hippopotamus really did live here and breed here too. Hence, mammals were not good indicators of temperature.

Prof. Prestwich referred to the observation of the president, that to consider the present subject thoroughly required the knowledge of the palæontologist, the anthropologist, the archrologist, and the geologist. He thought that it specially concerned the geologist with regard to the sequence of events. The palæontological evidence hardly presented sufficient differences. We had to deal with the sequence of man from his first appearance in time geo. logically to the present period. He would confine himself to the evidence in the south of England and in the north of France. In the south of England it was particularly clear and decisive the datum line was distinct. It was afforded by the deposit of the boulder clay, which ranged as far south as London. That represented the glicial period. The post-glacial period he con. sidered to be subsequent to the period of the deposit of the boulder clay. Most of the discoveries made in this country have been made in the districts of the south which have been covered by the boulder clay, and it is in the drift and gravel of the valleys excavated in the boulder clay of those districrs that the flint implements have been so largely found; therefore he believed that in all that area man is of post-glacial age. If we got two levels on either side of a valley, so many feet above sea-level, with the boulder clay cut off on either side, then of course the débris at the bottom of the valley would consist of gravel, and so on, derived from materials which had been formed by the destruction of the several strata which originally traversed that valley. The materials so spread out were necessarily newer than the boulder clay; consequently man in the valleys was post-glacial. There were sometimes two or three successive levels of gravels in those valleys. If a valley was excavated to a rertain depth, and a deposit was formed in which they could find no traces of the existence of man, whilst at another and deeper level flint implements were found, then man was introduced in that place only when the valley was excavated to its greatest depth and the gravel was spread out on the site now nearly occupied by our present rivers. Unfortunately the mammalian remains of those nearly connected periods were so alike that it was impossible to determine irom the distinction of age. Bone caves were.also found on the sides of valle, $s$ and in districts where there was scarcely any 